\title{
Contract is Not Promise; Contract is Consent
}

Randy E. Barnett

Georgetown University Law Center, rb325@law.georgetown.edu

Georgetown Public Law and Legal Theory Research Paper No. 11-29

This paper can be downloaded free of charge from:

https://scholarship.law.georgetown.edu/facpub/615

http://ssrn.com/abstract=1792586

Suffolk U. L. Rev. (forthcoming)

This open-access article is brought to you by the Georgetown Law Library. Posted with permission of the author. Follow this and additional works at: https://scholarship.law.georgetown.edu/facpub

Part of the Contracts Commons 


\title{
Contract is Not Promise; Contract is Consent
}

\author{
RANDY E BARNETT*
}

ABSTRACT: In the 1980s, Charles Fried was right to focus on what was missing from both the "death of contract" and "law and economics" approaches to contract law: the internal morality of contract. But he focused on the wrong morality. Rather than embodying the morality of promise-keeping, the enforcement of contracts can best be explained and justified as a product of the parties' consent to be legally bound. In this essay, I observe that, in Contract as Promise, Fried himself admits that the "promise principle" cannot explain or justify two features that are at the core of contract law: the objective theory of assent and the content of most "gap fillers" or default rules of contract law. After summarizing how consent to contract accounts for both, I explain that, whereas the morality of promise-keeping is best considered within the realm of ethics - or private morality - legally enforcing the consent of the parties is a requirement of justice - or public morality.

Charles Fried's Contract as Promise $e^{1}$ arrived on the scene in 1981 at exactly the right moment. In the 1970s, contract law scholarship had come to be dominated by two competing visions: the "contract as tort" vision associated with many scholars, but most pithily by Grant Gilmore in his highly influential The Death of Contract, ${ }^{2}$ which appeared in 1974; and the "contract as efficiency" vision associated with law and economics scholars, especially that of the prolific and accessible Richard Posner in his book The Economic Analysis of Law, ${ }^{3}$ the first edition of which was published in 1973.

Fried's "contract as promise" thesis was a welcome and much-needed defense of the traditional view of contract as protecting the "will" or choices of private parties. In it Fried defends what he calls "the promise principle," by which he meant "that principle by which persons may impose on themselves obligations where none existed before." To make his case, Fried engaged in a tour de force march through

\footnotetext{
*Carmack Waterhouse Professor of Legal Theory, Georgetown University Law Center. This essay was prepared for the symposium on "Contract as Promise at 30: the Future of Contract Theory," held at the Suffolk University Law School on March 15, 2011. It will appear in the Suffolk University Law Review.

${ }^{1}$ Charles Fried, Contract as Promise (1981).

${ }^{2}$ Grant Gilmore, The Death of Contract (1974).

${ }^{3}$ Richard A. Posner, The Economic Analysis of Law (1 ${ }^{\text {st }}$ ed. 1973).
} 
the conundrums of contract doctrine, separating those doctrines that could be defended as consistent with the best understanding of voluntary transactions, those doctrines that could best be understood as resting on alternative justifications that were consistent with the enforcement of voluntary transactions, and those doctrines that should be rejected because they are neither.

Perhaps due to Fried's systematic examination of the disparate contract law doctrines that so frustrate first year law students, for a work of serious contracts scholarship, Contract as Promise has remained a remarkably popular book, even some thirty years after its appearance. And it also inspired a coterie of contracts scholars, who took contract law after its publication, who have pursued and elaborated the "contract as promise" model.

By coincidence, in the Fall of 1981, I began a one year fellowship at the University of Chicago Law School after having served four years as a criminal prosecutor for the Cook County State's Attorney's Office in Chicago. My research agenda was to retool as a contracts scholar, having been inspired to do so by taking Roberto Unger's contract class at Harvard Law School in 1974-1975. In his course, the only time he ever taught Contracts, Unger had effectively critiqued the "liberal" conception of contracts. We read, among other things, Gilmore's Death of Contracts, and Unger provided his own unique take on contract law that has yet to be published to this day. And I later came to appreciate the extent to which Unger's critique of freedom of contract reflected that of Duncan Kennedy, who was then on the rise as a legal theorist of the private law, but who taught Contracts in another section.

As a law student sympathetic to freedom of contract, I found myself unable to answer Unger's challenge, but at the same time unwilling to accept his critique, engaging as it was. Also unsatisfied was Unger's colleague (and my torts professor) Charles Fried. His answer to Unger and others was Contract as Promise. But Fried's answer, while a great step forward, did not fully satisfy me. With his response in mind, I embarked on the writing that would lead to "a consent theory of contract," or what might be called "contract as consent."

I confess that I have not read Contract as Promise from cover to cover since my days at the University of Chicago. As a scholar, one has a tendency not to backtrack, which is why teaching is so valuable. It forces scholars to read, and reread, all the seminal cases and materials one might well never review. And that compels scholars to see these classic materials in a new light with each passing year. I accepted the invitation to participate in this symposium not only as an opportunity to pay homage to my professor Charles Fried, but as an inducement to revisit 
RANDY E. BARNETT

CONTRACT IS NOT PROMISE

PAGE 3

Contract as Promise to appreciate why it has endured so well for thirty years.

What I found upon my rereading was a book that exceeded my recollection of it. Not only does Fried's account of contract doctrine still seem fresh and insightful. It turns out that in several respects, he anticipated "contract as consent." Indeed, I can imagine that, if one changed its opening thesis from "contract as promise" to "contract as consent," much of the subsequent thesis could remain more or less intact, albeit with some important modifications and improvements.

In particular, one of the less satisfying aspects of Contract as Promise, and the reason it left me rather cold when it first appeared, is how willing it appears to so quickly shift away from the promise model to account for myriad doctrines. True, it claims that this shift does not undermine the promise principle. But it also insists that the promise principle does not account for many of the doctrines that are needed to supplement it. One comes away from the book, or at least I came away from the book, thinking that Fried opts for alternative principles on a seeming ad-hoc basis.

Or at least, that the promise principle on its own appears unable to justify much of what he himself thinks of as justified contracts doctrine.

In my view, "contract as consent" explains and justifies far more of contract law doctrine than does "contract as promise." And it avoids some of the problems created by viewing promises as the core of contractual obligation. But because consent and promise are so close to each other - and both ground contractual obligations in the voluntary choices of contracting parties - it is hard for some to distinguish these two alternative defenses of contractual freedom.

In these remarks, I will not be able to mount a comprehensive critique of either "contract as promise" or Contract as Promise. Instead, I want to briefly summarize some of the difficulties of this model and describe how it differs from contract as consent. But I also want to do one more thing I had not expected to do when I accepted the invitation to participate in this symposium. I wish to highlight the degree to which Fried's defense of "contract as promise" actually relies on arguments that are better understood as aspects of "contract as consent." In this regard, his instincts moved him in the direction of consent, even when his theory was ostensibly limited to promise. And his defense of contractual freedom was, I think, as a result, more powerful than it otherwise would have been. 
RANDY E. BARNETT

CONTRACT IS NOT PROMISE

PAGE 4

\section{Contract is Not Promise}

The thesis of Contract as Promise presents three major difficulties that undercut its claim to be either an explanation or justification for contract law. These concern (1) its inability to explain contract law's objective theory of assent as contractual, (2) its inability to understand contract law's "gap fillers" as contractual, and (3) its moralizing the enforcement of contracts in the wrong way. In this Part, I consider each in turn.

The Problem of the Objective Theory of Assent. In my 1986 article, $A$ Consent Theory of Contract, ${ }^{4}$ I presented a critique of "will theories" of contract that can also be taken as a critique of Fried's "contract as promise" thesis as well. Later, I refer to the "will principle" rather than will "theories," but I might just have well have called it the "promise principle" instead. According to the will or promise principle, commitments are enforceable because the promisor has "willed" or freely chosen to be bound by his commitment. Under the classical view, "the law of contract gives expression to and protects the will of the parties, for the will is something inherently worthy of respect." In this approach, the use of force against a reneging promisor is morally justified because the promisor herself has undertaken the obligation in question. A promisor cannot complain about force being used against her, since she created the obligation being enforced. Or, as Fried puts it: "An individual is morally bound to keep his promises because he has intentionally invoked a convention whose function it is to give grounds - moral grounds - for another to expect the promised performance." 7

In this way, the will (or promise) principle is able to distinguish contract from tort. In tort, the source of the obligation or "duty" is the law. In contract, the source of the obligation or duty being enforced is the promisor herself. The spirit of the will principle may best be exemplified by the traditional sentiment, often expressed by Nineteenth and early Twentieth century courts, that contracts require a "meeting of the minds." That mutual "assent" is thought necessary to create a contractual

\footnotetext{
${ }^{4}$ Randy E. Barnett, A Consent Theory of Contract, 86 Colum. L. Rev. 269 (1986). The next several paragraphs are based on $i d$. at 272-74.

${ }^{5}$ See Randy E. Barnett, Contracts: Cases And Doctrine 586 (4 ${ }^{\text {th }}$ ed. 2008$)$.

${ }^{6}$ Morris Cohen, The Basis of Contract, 46 HARv. L. REv. 553, 575 (1933).

${ }^{7}$ See FRIED, supra note 1, at 16 (emphasis added).
} 
RANDY E. BARNETT

CONTRACT IS NOT PROMISE

PAGE 5

obligation is quite harmonious with the will principle.

For its moral force, the promise principle depends upon the notion that contractual duties are binding because they are freely assumed by those who are required to discharge them. This position leads quite naturally to an inquiry as to the promisor's actual state of mind at the time of agreement - the so-called "subjective" viewpoint — and indeed most important contractual duties probably are subjectively assented to by the promisor. However, what of those manifested commitments that lack subjective assent? Without a genuine commitment by the person who is to be subjected to a legal sanction, enforcement would seem to be unjustified by the "will" of the promisee and, hence, it seems unsupported by the promise principle. After all, enforcement can hardly be based on either will or promise if the obligation was not chosen by the individual but instead was imposed by law the way that tort duties are.

Yet, it has long been recognized that a system of contractual enforcement would be unworkable if it required a subjective inquiry into the putative promisor's intent. Where we cannot discern the actual subjective intent or will of the parties, there is no practical problem since we may assume it corresponds to objectively manifested intentions. But where subjective intent can somehow be proved and it is contrary to objectively manifested behavior, the subjective intent should prevail if the moral integrity of the will principle is to be preserved.

Of course, any legal preference for the promisor's hidden subjective intent would disappoint a promisee who has acted in reliance on the appearance of a commitment. Moreover, permitting a subjective inquiry into the promisor's intent could also enable a promisor to fraudulently undermine otherwise perfectly clear agreements by generating and preserving extrinsic evidence of ambiguous or conflicting intentions. Such a strategy might create a de facto option in the promisor. The promisor could insist on enforcement if the contract continued to be in her interest, but if it were no longer advantageous, she could avoid the contract by producing evidence of a differing subjective intent. ${ }^{8}$ In sum, because the subjective approach relies on evidence inaccessible to the promisee, much less to third parties, an inquiry into subjective intent would undermine the security of transactions by greatly reducing the reliability of contractual commitments. As philosopher David Hume, upon whom Fried relies, ${ }^{9}$ observed over two hundred years ago:

\footnotetext{
${ }^{8}$ For a case in which a court suspected a party of using the "mail-box rule" in such a fashion, see Cohen v. Clayton Coal Company, 86 Colo. 270, 281 p. 111 (1929).

${ }^{9}$ See e.g. FRIED, supra note 1 , at $1,15,137,138,150-51$.
} 
If the secret direction of the intention, said every man of sense, could invalidate a contract, where is our security? And yet a metaphysical schoolman might think, that where an intention was supposed to be requisite, if that intention really had no place, no consequence ought to follow, and no obligation be imposed. ${ }^{10}$

Not surprisingly, despite the oft-expressed traditional sentiment that contracts require a "meeting of the minds," the objective approach has largely prevailed. A rigorous commitment to a will theory conflicts unavoidably with the practical need for a system of rules based to a large extent on objectively manifested states of mind. So too does the promise principle for the same reasons, unless it is qualified in some manner.

Of course, because a person's objective manifestations generally $d o$ reflect her subjective intentions, the doctrinal requirement of mutual assent tends in the vast majority of cases to honor the promise principle. And, consistent with the these principles, (a) the reasonable or objective meaning of assent may be overridden by proof of a contrary subjective agreement between both parties, and (b) when a promisee has access to the subjective or actual understanding of the promisor, he may not rely on the "objective" or reasonable meaning of the promisor's conduct. In such circumstances, the courts will enforce the subjective over the objective meaning of assent.

Nonetheless, the promise principle has difficulty explaining the enforcement of the objective agreement where it can be shown that the subjective understanding of a promisor differs from her objectively manifested behavior. Fried sees this alltoo-clearly but, with typical candor, he goes the other way: "Another of the classical law's evasions of the inevitability of using noncontractual principles to resolve failures of agreement is recourse to the so-called objective standard of interpretation." 11

In short, Fried thinks that the objective approach to contract cannot be justified by the promise principle. "In the face of a claim of divergent intentions, the court imagines that it is respecting the will of the parties by asking what somebody else, say the ordinary person, would have intended by such words of agreement."12 Instead, such an approach entails "imposing an external standard on the parties"

${ }^{10}$ David Hume, An Inquiry Concerning the Principles of Morals 30 n. 5 (C. Hendel ed. 1957) (1st ed. 1751).

\footnotetext{
${ }^{11}$ FRIED, supra note 1 , at 61 .

${ }^{12} I d$.
} 
based on "nonpromissory standards of justice."13 However, if contract equals promise, and promise cannot justify this mainstay of contract law doctrine as "contractual," this is a major weakness of contract as promise. Contract as promise may not have been refuted, but this is strike one.

The Problem of "Gap Filling." A second serious problem is created by the promise theory's exclusive focus on promises once it is conceded, as it must be, that many real-world contract law problems arise precisely because parties have unavoidably left "gaps" in their promises. This has led some contracts theorists to argue that other nonpromissory principles must be used to determine the "gap-filling" rules of contract law. ${ }^{14}$ In Contract as Promise, Fried takes exactly this position. Where gaps exist in a contract, "the court is forced to sort out the difficulties that result when parties think they have agreed but actually have not. The one basis on which these cases cannot be resolved is on the basis of the agreement - that is, of contract as promise." "In his analysis of the inevitable "gap-filling" that contract law provides, he readily concedes that the "gaps cannot be filled, the adjustments cannot be governed, by the promise principle."16 When combined with its inability to justify the objective approach to contract, this inability to "fill gaps" is strike two for contract as promise.

The Problem of Moralizing Contract. But there is one more problem that goes to the very heart of Contract as Promise: the claim that the obligation to keep one's promises is a moral one.

An individual is morally bound to keep his promises because he has intentionally invoked a convention whose function it is to give grounds - moral grounds - for another to expect the promised performance. To renege is to abuse a confidence he was free to invite or not, and which he intentionally did invite. To abuse that confidence now is like (but only like) lying: the abuse of a shared social institution that is intended to invoke the bonds of trust. ${ }^{17}$

\footnotetext{
${ }^{13} I d$.

${ }^{14}$ See Randy E. Barnett, The Sound of Silence: Default Rules and Contractual Consent, 78 VA. L. REV. 821, 822-23 (1992).

${ }^{15}$ FRIED, supra note 1 , at 60.

${ }^{16} I d$. at 69.

${ }^{17} I d$ at 16 (footnote omitted).
} 
Recently, Fried has explained what he means by "morality," saying that "[m] orality is concerned with how people should lead their lives and how they should treat each other."18 And he further elaborated:

\begin{abstract}
Morality . . . condemns a way of life indifferent to the well being of others, and even more strongly condemns pursuits that are constituted by the frustration, humiliation, or destruction of others. By contrast, it enjoins each actor to respect the other's humanity - that is, the feeling, judging, and striving nature of other persons - and celebrates pursuits that involve others not only without disrespecting them (that is, "using" them in Kantian terminology), but also by furthering their own pursuits as they further the actor's pursuit. ${ }^{19}$
\end{abstract}

But basing contracts on this capacious conception of morality invites courts to inquire into the moral merits of the respective parties. ${ }^{20}$ Indeed, by justifying contract as a species of enforcing purely moral commitments, it seems tantamount to enforcing virtue. ${ }^{21}$ Such an open-ended rationale leads to serious problems for the value of freedom of contract that Fried is defending in Contract as Promise. First, it (2007).

${ }^{18}$ Charles Fried, The Convergence of Contract and Promise, 120 HARV. L. REv. F. 1,

${ }^{19}$ Id. at

${ }^{20}$ See e.g. Seana Shiffren, The Divergence of Contract and Promise, 120 HARV. L. REv. 708, 725 (2007) ("[W] a number of factors to which the law is insensitive, including the closeness of the relationship, the history of the relationship, the reason for breach, the reason the promisor wants to shift the burden, and how cumbersome mitigation activities would be."); and id., Could Breach of Contract be Immoral? 107 MicH. L. REV. 1551, 1567 (2009) ("I am not arguing that breach of contract is always immoral, just that it may sometimes be. Nothing I have argued precludes the judgment that some forms of breach are morally permissible.")

${ }^{21}$ But see id. at 752 (denying that contract law is "an effort to get people to act virtuously, to prompt people to keep their promises for the right reasons, to ensure that private relationships go as well as possible, or to get people to make promises when morally appropriate to do so.") According to Shiffren, contract law "is not an effort to legalize as much as possible the interpersonal moral regime of promising, but rather to provide support for the political and public values associated with promising." $I d$. I view this effort by Shiffren to distinguish the morality of contract that is the core of her approach from enforcing virtue as reintroducing into her analysis the distinction I make below between "public" and "private" morality. 
commits courts to enforcing promissory commitments that the parties themselves may never have contemplated as "contractual" or legally enforceable, thereby undermining the value of freedom from contract. Second, once the moral behavior of the promissor is deemed relevant to the issue of enforceability, the promise theory also appears to make relevant to the issue of enforcement other moral aspects of the promisor's behavior that may argue against enforcement, thereby undermining the value of freedom to contract. In this manner, the common-law rights of contract can come to resemble the judicial discretion of a court of equity.

Those unsympathetic to freedom of contract will not be bothered by the implication of moralizing contract in this way. But Fried himself wrote Contract as Promise as a way to defend contractual freedom. "[T] he law of contracts facilitates our disposing of [our] rights on terms that seem best to us." "22 For those who share this view, this problem with contract as promise should be considered strike three.

\section{Contract is Consent}

I do not intend to rehearse all the reasons I have previously advanced for why the overarching organizing principle of contract is not promise, but consent. My recent book, Contracts, ${ }^{23}$ explains how and why discerning the existence and meaning of that consent comprises the core of the law of contract. Whereas the duties enforced by torts may or may not be a product of the consent of the person on whom they are imposed, every contract begins with the consent of the parties.

I shall only briefly describe here the criterion of contractual enforceability that I have elaborated elsewhere over the past twenty-five years. ${ }^{24}$ It is a criterion that is

${ }^{22}$ FRIED, supra note 1 , at 2.

${ }^{23}$ See RAndy E. BARnett, Contracts: The Oxford introductions to U.S. LAw (2010). In a real sense, Contracts is my answer both to Fried's Contract as Promise and to Gilmore's The Death of Contracts, although its survey of the principal doctrines of contract law resembles the former more than the latter.

${ }^{24}$ In addition to BARnetT, supra note 23, see Randy E. Barnett, Consenting to Form Contracts, 71 Fordham L. Rev. 627 (2002); id. . . a and Contractual Consent, 3 S. CAL. InTERDiSC. L. J. 421 (1993); id., Rational Bargaining Theory and Contract: Default Rules, Hypothetical Consent, the Duty to Disclose, and Fraud, 15 HARV. J. L. \& PUB. PoL'y 783 (1992); id., supra note 14; id., Conflicting Visions: A Critique of Ian Macneil's Relational Theory of Contract, 78 VA. L. REV. 1175 (1992); id., The Function of Several Property and Freedom of Contract, 9 Soc. PHIL. \& PoL'Y 62 (1992); id., Some Problems With Contract as Promise, 77 Corn. L. Rev. 1022 (1992); id., The 
explicitly acknowledged in English law and which I think underlies much of the doctrine of contract law we have inherited: courts should presumptively enforce private commitments when there exists a manifested intention to create a legal relation. Another formulation of this approach is that, to determine the prima facie case of contract, we should determine whether there was a manifested intention to be legally bound. I refer to this criterion, in short, as consent.

This special sense of "consent" is to be distinguished from promise. To promise is to commit to do or refrain from doing something. To consent to contract is to commit to be legally responsible for nonperformance of a promise. So consent is a commitment in addition to whatever moral commitment inheres in a promise.

Moreover, contractual consent is to be distinguished from subjective assent. Consent is the voluntary communication by one person to another person of a particular message: that one intends to alter an already existing legal relation between the parties or to create a new one. ${ }^{25}$ Some such criterion seems to have been incorporated into U.C.C. $\S 2-204(3)$, which permits the enforcement of a contract with one or more open terms "if the parties intended to make a contract and there is a reasonably certain basis of giving an appropriate remedy." 26

A "consent theory" of contractual enforcement provides a general criterion of contractual enforceability that strikes a reasonable and workable balance among the party-based, substance-based and process principles that comprise the core concerns of contract. Requiring a manifested intention to be legally bound facilitates the will or private autonomy of the parties, since one's manifested intention is highly likely to reflect an underlying subjective assent. The existence of a manifested intention to be legally bound also helps distinguish those commitments upon which

Internal and External Analysis of Concepts, 11 Cardozo L. Rev. 525 (1990); id. Squaring Undisclosed Agency Law With Contract Theory, 75 CAL. L. REV. 1969 (1987); id, supra note 4; id., Contract Remedies and Inalienable Rights, 4 Soc. PHIL. \& POL'Y 179 (1986)[hereinafter cited as "Inalienable Rights"]; id. Contract Scholarship and The Reemergence of Legal Philosophy (book review), 97 HARV. L. Rev. 1223 (1984); and Randy E. Barnett \& Mary Becker, Beyond Reliance: Promissory Estoppel, Contract Formalities and Misrepresentation, 15 HofsTRA L. REV. 445 (1987). The next several paragraphs are based on BARNETT, supra note 5, at 602-04.

${ }^{25}$ Because every person stands in some legal relation to every other person, analytically there is no real difference between altering a pre-existing legal relationship and creating a new one. Still, it is useful to distinguish between creating a contractual relationship between parties who previously had no such relationship and altering a contractual relationship that already exists.

\footnotetext{
${ }^{26}$ UNIFORM COMMERCIAL CODE $§ 2-204(3)$.
} 
reliance is justified and merits legal protection from those that do not. Although restitution-based liability is not limited to contract - it can provide an independent basis for legal enforcement apart from consent - the existence of a party's consent to be legally bound justifies forcing that party to disgorge her enrichment.

Adherence to a criterion of consent would tend to limit enforceability to value-enhancing or efficient commitments (whether gratuitous or as part of an exchange) in which, ex ante, the parties view enforceability to be worth more to them than its costs. To the extent that parties themselves are normally the best judge of their own interests, the substance of agreements that result from the parties' consent are also likely to be fair. But to the extent that normal conditions do not obtain, the parties' consent provides only a prima facie basis for enforceability. Contract defenses that allow consent to be set aside under circumstances such as fraud, duress, various forms of incompetence, undue influence, etc. identify circumstances where the consent of the parties may not produce substantively fair or efficient agreements.

Finally, the criterion of consent helps place the bargain principle in proper perspective. The existence of a bargain in a commercial context is very likely to indicate the existence of an intention to be legally bound. The absence of bargains in noncommercial settings is apt to reflect the absence of such consent. Nonetheless, the existence of a bargain is not dispositive of the issue of consent. For example, the presence of a bargain in the commercial context could be negated by evidence that the parties did not intend to be legally bound. By the same token, the absence of a bargain in the noncommercial context could be compensated by the existence of some other indicia of intention to be legally bound - perhaps a formality such as socalled "nominal consideration."

Furthermore, in many promissory estoppel cases, some indicia of consent other than bargain appears to be present. So we may be wrong to conceive of the doctrine of promissory estoppel solely in terms of reliance. And under some circumstances, consent of a promisor to be legally bound may be manifested by her silence in the face of substantial reliance by the promisee of the sort that would not be incurred without a commitment to be legally bound.

Like any rule of law, however, limiting even prima facie contractual enforcement to those commitments that are accompanied by some formal or informal manifestation of intention to be legally bound will lead to some cases of over- and underenforcement from the standpoint of the underlying principles of will, reliance, fairness, restitution, and efficiency. On the one hand, if limited to highly formalized manifestations of consent, it will fail to capture all promises that intuitions deem to be enforceable. On the other hand, if expanded to include highly contextual indicia 
of consent such as those just discussed, it may lead to the enforcement of some commitments that should be left unenforced. Moreover, standing alone, consent to be legally bound does not immediately explain the limitations on its application, for example, in cases involving promises to perform illegal acts or consent to servitude. ${ }^{27}$ Finally, although the consent criterion accounts for much of existing contract doctrine, this "fit" alone does not entirely justify a conclusion that it should be the sole criterion of contractual obligation. ${ }^{28}$

My purpose here is simply to compare "contract as promise" with "contract as consent." In particular, contract as consent better explains and justifies the objective theory of assent and the default rules that comprise the bulk of contract law.

The Objective Theory of Assent. ${ }^{29}$ The law of contracts, property, and torts can be viewed as defining boundaries within which each person may make her own choices in pursuit of her own happiness. You are allowed to do what you wish with what is yours (as defined by property law), provided that you do not infringe (as defined by tort law) on the property of others - including the inalienable property rights one has in one's own body. Contract law provides the means by which a person can transfer her property to another by her consent (although wholly gratuitous transfers are considered to be an aspect of property law, not contracts).

So contract, property, and torts - along with other subjects such as restitution — can be viewed as providing the legal boundaries that define the scope of individual liberty and distinguish rightful from wrongful conduct. To act rightfully is to remain within one's boundaries; wrongful conduct is when one crosses over into another's rightful domain. These "boundaries" do not presuppose an atomistic individualism in which each person is an island. Contract, property, and torts are thoroughly relational or social. They address the fact that each person's actions can potentially affect others by distinguishing those actions that are nevertheless permissible from those that are not. In a world of atomistic individuals — or Robinson Crusoes on desert islands - no such concepts would be needed.

\footnotetext{
${ }^{27} \mathrm{My}$ treatment of this subject examines the underlying entitlements that parties bring to transactions and which are transferred by their consent. Because some of these entitlements are inalienable, they cannot be transferred even with the consent of the parties. See Barnett, Inalienable Rights, supra note 24 .

${ }^{28}$ For additional normative support of the consent criterion, see BARNETT, supra note 23, at $127-47$

${ }^{29}$ This section is drawn from id. at $72-74$.
} 
Fried agrees with this. "The law of property defines the boundaries of our rightful possessions, while the law of torts seeks to make us whole against violations of those boundaries, as well as against violations of the natural boundaries of our physical person." ${ }^{30}$ And contract? "[T] he law of contracts facilitates our disposing of these rights on terms that seem best to us. ${ }^{\prime 31}$ So far so good. But this analysis leads not to enforcing our promises per se, but to enforcing consensual exchanges of entitlements - and an objective theory of contract, modified by a "subjective twist."

If the law is doing its boundary-defining job, each person should know, or be able to find out, what physical resources belong to her for her use, and what belongs to others, as well as how to use what is hers without interfering with the like rights of others. In this way, the existence of these legal boundaries, or limits on the scope of rightful conduct, provides vital information to all those who might wish to avoid disputes and respect the rights of others, provided they know what those rights are. Potential conflicts between persons who might otherwise vie for control of a given resource are thus avoided, and society as a whole is rendered more harmonious.

In contract law, this informational or "boundary-defining" function is served by requiring that consent to alienate or transfer one's rights must be manifested by one party to the other in a manner that provides a criterion of enforcement. Without a manifestation of assent that is accessible to all affected parties, the law will have failed to identify clearly and communicate to both parties (and to third parties) the rightful boundaries that must be respected. Without such communication, parties to a transaction (and third parties) cannot accurately ascertain what constitutes rightful conduct and what constitutes a commitment on which they can rely. Disputes that might otherwise have been avoided will occur, and the attendant uncertainties of the transfer process will discourage beneficial reliance.

Although requiring the consent of one party to alienate or transfer her rights to another is essential to achieve the boundary-defining function of law, whether one has consented to a transfer of rights generally depends not on one's subjective opinion about the meaning of one's freely chosen words or conduct, but on the ordinary meaning that is attached to them. If the word "yes" ordinarily means yes, then a subjective and unrevealed belief that "yes" means no is generally immaterial. Only a general reliance on objectively ascertainable assertive conduct will enable a

\footnotetext{
${ }^{30}$ FRIED, supra note 1 , at $1-2$. He provides a nice concise defense of property rights $i d$. at $100-01$.

${ }^{31} I d$. at 2 .
} 
legal system to perform its boundary-defining function.

It is true that, because one of the core concerns of contract is that the actual or inner subjective welfare of each party be increased, ${ }^{32}$ contracts are interpreted with an eye towards honoring the actual intentions of the parties. In the main, genuinely consensual exchanges are value enhancing. Because we cannot read each other's minds, however, only the "reasonable" or objective interpretation of the commitment will establish the clear boundaries that are required for persons to pursue happiness without interfering in the like pursuit by others of their happiness.

On the other hand, the "objective" approach to assent incorporates a subjective twist. Before one party may rely on the "objective" assent of another, that party must have subjectively understood the other party to have intended that meaning and actually relied upon it. ${ }^{33}$ And, when it comes to discerning the meaning of the parties' agreement, where both parties subjectively agree on an idiosyncratic meaning - or when one party is subjectively aware of the idiosyncratic meaning held by the other — the idiosyncratic meaning will trump that of the reasonable person. ${ }^{34}$

There is nothing novel or revolutionary about contract law's concern for the protection of reliance by one contracting party on the commitment of the other. One of the most important functions of the institution of property rights is to legally protect certain expectations of the rights holder so that she may rely on the continued use of certain resources. For example, an owner of land relies upon her title when she invests in building a house or a factory upon it, because she expects that her title will be honored by a legal system in the future. She also relies upon her title when she leaves town on vacation, expecting her property to still be hers when she returns.

The alleged conflict in contracts between "will" and "reliance" results from focusing on one party to a transaction or the other. But, like property, the boundarydefining aspect of contract defines and regulates the relations between persons. Basing the prima facie case of contractual obligation on the manifestation of consent to be legally bound facilitates this relational quality of contract law.

\footnotetext{
${ }^{32}$ See BARNETT, supra, note 23 at xix-xxi (discussing the three core concerns of contract law).

${ }^{33}$ See id. at 71-72.

${ }^{34}$ See id. at 85-86.
} 
From Gap-Filling to Default Rules. ${ }^{35}$ As was seen in Part I, because he equates contract with promise, Fried concludes that an appeal to extracontractual considerations becomes necessary when "gaps" arise in one's promise. This stance stemmed not only from his commitment to contract as promise, but also from the "gap-filling" conception of contract law that was regnant when he wrote.

For a long time, many of the rules of contract law were called "gap fillers," which emphasized that they applied precisely when the agreement — or promises of the parties did not address the issue governed by the rule. In short, the rules of contract law applied when there was a "gap" in the assent of the parties. By adopting this terminology, the consent of the parties could be cast as irrelevant to contract law because contract law applied precisely when the consent of the parties did not exist. As we saw, this led Fried to conclude that much of contract law itself, not being based on the promises of the parties, was noncontractual.

Since Contract as Promise appeared, however, this "gap-filling" image of contract law has been supplanted to a great extent by the image of contract law as "default rules." The default rules of contract law are like the default margins supplied by your word processing program that apply unless you change them. As such, the rules of contract law apply unless the parties "contract around" them by putting a different term in their agreement. Although there are some contract law doctrines that cannot be contracted around, the great majority of contract law rules are default rules. Indeed, most of the cases studied in contracts courses would not be included had the parties only inserted an express clause to cover the issue that later arose.

Whereas the image of "gap fillers" emphasized the discontinuity between contract law and the consent of the parties, the concept of default rules highlights an intimate connection between contract and consent. Notwithstanding that the rules of contract law are provided by the courts or legislature rather than by the parties, under certain circumstances, the parties can be said to have consented to the application of those background rules by remaining silent and accepting their operation.

Some have maintained that the cost of contracting should be reduced by applying contract law rules that most parties would agree to, placing the onus on the minority of dissenting parties to expressly contract around the rules. While this may sometimes be a good way of selecting contract law rules, other considerations may also be taken into account. In particular, the background default rules can be chosen to reduce misunderstandings about the terms that will actually apply in the event of

\footnotetext{
${ }^{35}$ This section is based on $i d$. at xxi-xxii \& 99-100. For a much more extensive account of default rules and consent, see Barnett, supra note 14.
} 
a dispute, even if that means applying default rules that all, or nearly all, parties expressly contract around. When this is the case, far from being inimical to consent, the law of contract is greatly influenced by the goal of increasing the likelihood that both parties are consenting to the same thing.

So far as freedom of contract is concerned, it sometimes does not matter what the "gap filling" default rule is, so long as the parties had access to it. It is rational for repeat players (or one-shot players in large transactions) to learn the content of the default rules via their lawyers. By remaining silent they have consented to whatever term the law supplies as a gap-filler and the conflict between freedom from and freedom to is ameliorated. Such parties who do not contract around these default rules can realistically be said to have objectively manifested their consent to them.

But the default rules supplied by contract law will also apply when one or both parties are "rationally ignorant." It is rational to remain ignorant of the background rules of contract law when the cost of finding out the background rules that will be supplied by a court, for example by hiring a lawyer, is greater than the risk of agreeing to an undesired term. When this is the case, as it often is for oneshot players in low stakes contracts, if courts supply a term that rationally ignorant parties would expect, the agreement is likely to be consistent with their consent.

For this reason, contract law should confine itself to common sense default rules that unsophisticated parties would expect. When both parties are one-shot, rationally-ignorant players, a common-sense default rule will likely reflect their tacit intentions. Repeat players who do not like the default rule are free to contract around it by inserting an express clause to the contrary in the agreement. By so doing, they will put the rationally ignorant party on notice that the term actually governing the transaction is not one that it would ordinarily expect, so they can decide whether to accept or reject the agreement with this unexpected term in mind.

In this way, default rules reflecting the conventional understanding of the less sophisticated party will induce contracting behavior by repeat players that will minimize latent subjective disagreements, and thereby reduce the likelihood that the court will inadvertently impose upon the parties a term they did not expect, and to which it cannot be said they objectively consented.

Fried anticipated much of this analysis of the role of conventions in filling gaps. "Since actual intent is (by hypothesis) missing, a court respects the autonomy of the parties so far as possible by construing an allocation of burdens and benefits that reasonable persons would have made in this kind of arrangements. ${ }^{136}$ He then

\footnotetext{
${ }^{36}$ FRIED, supra note 1 , at 73 (emphasis added).
} 
immediately says this "treats the contract as a kind of charter or constitution for the parties' relation." ${ }^{37}$ Had he not been blinded by his vision of contract as promise, he could have seen the next step: consent to the "charter or constitution" of the parties is simply consent to contract!

Yet his commitment to contract as promise leads Fried to shrink from this conclusion. After asserting that "contractual accidents occur precisely because no mutual engagements have been made," he concludes that contract law constructs "a kind of nonconsensual penumbra" around the "consensual core." ${ }^{38}$ And how does it construct this penumbra? "Obviously some standard of sharing external to the intention of the parties must control." ${ }^{39}$ By his account then, this standard is outside of contract as promise, and therefore outside contract.

But "contractual accidents" not covered by express agreements fill the pages of every contracts casebook. Indeed, very few of the classic cases of contract law would have existed had the parties expressly anticipated what precisely occurred. In effect, Fried must consider most of the actual law of contract to be noncontractural because it is not based on promise. He must abandon much of contract law to noncontractual considerations. This cannot be right.

Had the concept of default rules been available when he wrote, Fried might have been tempted to claim that the content of default rules are imported into the tacit understandings that surround an express promise. This would not have solved his basic problem, however, unless he conceded that there was not one, but two "promises": the promise to perform, and the promise to be bound by the default rules supplied by the law of contract. This second commitment is not really a promise; it is simply the consent to be legally bound.

That consent to be legally bound is not a second "promise" was understood by Samuel Williston, the father of the modern promise theory of contract that, thanks to him, was embodied in the Restatement of Contracts. Williston made exactly this point when defending his proposed Uniform Written Obligations Act that would enforce a written promise without bargained-for consideration "if the writing also contains an additional express statement, in any form of language, that the signer

\footnotetext{
${ }^{37} I d$.

${ }^{38} I d$. at 72 . Notice the use of "consensual" and "nonconsensual."

${ }^{39} I d$.
} 
intends to be legally bound." 40

When asked by a commissioner whether, under Williston's proposal, "an express promise . . . would need another express promise to be added to it," he replied: "Another express statement that you intend to be legally bound. That is not another express promise, but a statement that you intend your promise not simply to create the moral obligation which attaches to every promise, but you intend that it shall create a legal obligation." ${ }^{41}$ Although not a promise, such a statement would be a manifestation of intention to be legally bound or what I call "consent."

Because it explains and justifies as contractual both the objective theory of contract along with its subjective twist, and the bulk of the default rules supplied by the law of contract, contract as consent is superior to contract as promise. And, though Fried was right to shift our focus to moral concerns, his focus on contract as promise is problematic because it invites importing considerations of morality or virtue into the interpersonal law of contracts. This is because Fried mistakenly focused on what might be called "private" as opposed to "public" considerations of morality.

\footnotetext{
${ }^{40}$ Uniform Written Obligation Act $\S 1$.

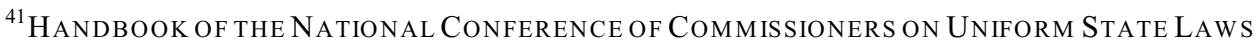
\& Proceedings of the Thirty-Fifth Annual Meeting, Detroit, Michigan, Seventh Session, Friday, August 28, 1925, as it appears in BARNETT, supra note 5, at 703.
} 


\section{The Public Morality of Contract}

The importance of "contract as consent" as opposed to "contract as promise" has come to be recognized by a new generation of contract scholars each of whom have questioned the model of contract as promise. I am thinking of such writers as Aditi Bagchi, ${ }^{42}$ Andrew Gold, ${ }^{43}$ Dori Kimel, ${ }^{44}$ and my colleague Greg Klass. ${ }^{45}$ I do not claim that each of these writers adopts what I call "a consent theory of contract" in toto. To the contrary, each has been critical of aspects of my approach. But each has also expressed grave skepticism of the "contract as promise" model and sympathy for a consent-based alternative to it. These scholars do not deny that there is a morality of contract, but insist it is not the same morality as promise.

Charles Fried was entirely correct to notice something missing from the "law and economics" and "death of contracts" models of contract in vogue when he wrote Contract as Promise. And that something could be called "morality." But "morality" is ambiguous insofar as it has more than one aspect. And the morality of promise-keeping is neither the only nor the best conception of morality to explain contractual obligation and distinguish contract from tort.

One way to express this is to distinguish "private" from "public" morality. Private morality governs the way one ought to live one's life. It identifies the duties one owes to oneself and to others. The term "ethics" perhaps best describes this moral domain. In contrast, public morality defines when coercion may be justifiably used against an individual for breaching a duty. The term "justice" best describes this moral domain. The old distinction between "perfect" and "imperfect" rights and

\footnotetext{
${ }^{42}$ See Aditi Bagchi, Separating Contract and Promise, Florid a ST. L. REv. (forthcoming) ("It is appropriate to ask whether a party spoke and acted in a way that made it reasonable for the other party to believe that she intended to be bound. But the inquiry cannot end there.").

${ }^{43}$ See Andrew S. Gold, A Property Theory of Contract 103 Nw. U. L. REv. 1, 61-62 (2009) ("A promisor's consent is necessary to a contractual obligation. However, contractual promises also depend on the acts of the promisee, and it is this feature that makes contracts binding.")

${ }^{44}$ See Dori Kimel, From Promise to Contract: Towards a Liberal Theory of CONTRACTS 136-42 (2005) (discussing “intention to create contractual relations”).

${ }^{45}$ See Gregory Klass, Intent to Contract, 95 VA. L. REV. 1437 (2009) (examining doctrinal rules as reflecting in various ways the parties' intentions to be legally bound).
} 
duties also captures these two moralities. Perfect rights" right to that" - and perfect duties are enforceable; imperfect rights and duties are unenforceable and rely on suasion.

Lon Fuller offered a similar distinction between the "morality of aspiration" and the "morality of duty." The "morality of aspiration ... is the morality of the Good Life, of excellence, of the fullest realization of human powers." ${ }^{, 47}$ In contrast, the "morality of duty" provides "the basic rules without which an ordered society is impossible, or without which an ordered society directed toward certain specific goals must fail of its mark." 48 The morality of duty "does not condemn men for failing to embrace opportunities for the fullest realization of their powers. Instead, it condemns them for failing to respect the basic requirements of social living.",49 With respect to each other, "[w]here the morality of aspiration starts at the top of human achievement, the morality of duty starts at the bottom." ${ }^{\circ 0}$

Fried himself once offered a metaphor that distinguished between the realm of "philosophy" and the domain of "law." Philosophy proposes "an elaborate structure of arguments and considerations that descend from on high but stop some twenty feet above the ground." ${ }^{\text {1 } 1 ~ I n ~ c o n t r a s t, ~ "[i] t ~ i s ~ t h e ~ p e c u l i a r ~ t a s k ~ o f ~ t h e ~ l a w ~ t o ~}$ complete this structure of ideals and values, to bring it down to earth; and to complete it so that it is firmly and concretely seated, so that it shelters real human beings against the storms of passion and conflict."

According to Fried, "[t]he law is really an independent, distinct part of the structure of value." According to Fried, "[t]he lofty philosophical edifice does not determine what the last twenty feet are, yet if the legal foundation is to support the whole, then ideals and values must constrain, limit, inform, and inspire the

\footnotetext{
${ }^{46}$ See e.g. Adam Smith, Lectures on Jurisprudence 5 (Oxford ed., 1978) (Liberty Press reprint 1982) ("The end proposed by justice is the maintaining men in what are called their perfect rights").

${ }^{47}$ Lon L. Fuller, The Morality of Law 5 (Rev. Ed. 1964).

${ }^{48}$ Id. at $5-6$

${ }^{49} I d$. at 6

${ }^{50} I d$. at 5 .

${ }^{51}$ Charles Fried, Rights and the Common Law, in Utility And Rights 231 (R.G. Frey ed. 1984).
} 
foundation - but no more." On this account, if the institution "promise" lies within the realm of philosophy, as it clearly seems to in Contract as Promise, then Fried's metaphor instructs that it is "independent" from and "does not determine" what constitutes the actual law of contract.

Viewed this way, the private morality of promise resides in the realm of ethics or what Fried calls "philosophy." In contrast, the morality of contract resides in the realm of justice to be governed by what Fried calls "law." ${ }^{52}$ In Fullerian terms, whereas the ethical duty to keep one's promises is part of the private morality of aspiration, the duty to adhere to one's contractual commitments is part of the public morality of duty and is a requirement of justice. In his timely and worthwhile effort to ground contract in morality, Fried made a category mistake by focusing on the wrong moral construct. And this mistake resulted in his inability to reconcile much of the actual law of contract with the internal morality of contract.

\section{CONCLUSION}

Contract as Promise is a remarkable intellectual accomplishment for which Professor Fried should be proud. It made, and continues to make, a signal contribution to our understanding of contract law. For those who have accepted the contract as promise model, Fried correctly identified the core of contractual obligation. For those who, like me, reject contract as promise, Fried's contribution is two-fold. First, he stood astride the momentum among contracts theorists to reject freedom of contract and collapse contract into tort and said "stop!" And stop it did. Second, his clear explication of the model of contract as promise, along with his candid admission of its limits, opened a theoretical space for a model of contractual obligation that better comports with the distinction in morality between the right and the good and that better explains and justifies the law of contract: contract as consent.

${ }^{52}$ I examine the relationship between justice and the rule of law at length in RANDY E. Barnett, The Structure of Liberty: Justice And the Rule of LaW (1998). 